\title{
Preface: Converging Stories
}

This book tells related stories about health politics and policy in the United States during the past century. The story that frames the book is the recent convergence of science and governance in policy for covering pharmaceutical drugs in public programs in most American states. The other stories explain why and how this convergence occurred.

A story fundamental to convergence is how politics has influenced the questions, methods, and reception of research on health services during the past century. The politics of research is part of a larger political struggle over who will do what, to, for and with whom, using what resources, to prevent and treat disease and its consequences. Interest groups are central in politics. But health politics is also about competing ideas and values that become conflicting opinions about power and money-especially opinions about social justice, the accountability of health professionals, the uses of technology, and the missions, structure and management of health-care organizations. The burden of disease and disability, and how it changes over time, is a constant, though often understated, force in the politics of health.

Another essential story in this book is how officials of state government have used policy to protect, maintain, and improve the health of populations and the individuals who comprise them. Much of the health policy that states have made and implemented since the nineteenth century has been independent of the federal government. State policy has often responded to federal mandates and incentives. But states have also influenced federal policy.

The history of the politics of research on health services and of governance in the states made convergence possible. Events in the general economy and in state and national politics made it feasible. Particular policymakers in state government and their advisers made it happen. 
Two related stories about these policymakers thread through the book. One is how they learned about the methods and came to appreciate the potential uses of research on health services. The other story is how they initiated, sustained, and defended the convergence of science and governance.

There are grounds for anxiety about the fragility of convergence, as well as for predicting that it will expand in scope. I also tell and assess these potential stories.

The stories in this book are grounded in my reading of archival and published primary sources and draw on an extensive secondary literature. But I also use my experience of helping to make and implement policy over four decades.

For most of my career, I compartmentalized my work in public affairs and research. During the 196os I recognized that I was committed to both government work and scholarship. I observed, however, that many public officials are dismissive of intellectuals in government, and that many academics assume that public officials are their inferiors in conceptualizing and analyzing problems and potential solutions to them.

I separated my careers in order to achieve professional standing in each of them. I achieved separation by devising different voices for writing in each career; and named them the Narrator and the Bureaucrat in an essay published in $1985 .{ }^{1}$ The Narrator wrote mainly for people who did research, health professionals, advanced students, and, when he could, for general readers. The Bureaucrat wrote for people who worked in the legislative and executive branches of federal, state, and local government.

The Narrator was "a relativist, an ironist, an existentialist"; an exemplary academic of his generation. He "believes that there is no past except what we create in the present and that most problems that now appear to be solved will, in time, most likely also appear to be trivial."

The Bureaucrat, in contrast, was "a technocrat, a moralist, a cynic." He was a technocrat because making policy requires immersion in esoteric details; a moralist because policymakers must assess value and make hard choices to allocate scarce resources; and a cynic because most people interpret the past and try to shape the present in ways that promote their ideology or self-interest. To be effective in politics, however, cynics must attend to their obligations. The Bureaucrat was, therefore, intensely loyal to his friends.

The Narrator and the Bureaucrat had some success for three decades. Academics did not condemn the Narrator's articles and books for having polemical purposes or for being autobiography disguised as history. The 
Bureaucrat wrote a vast amount of ephemeral prose that helped to create, defend, and, at times, prevent particular policy.

The Narrator and the Bureaucrat began to collaborate in 1993 when the Narrator wrote the first four chapters of a book and the Bureaucrat wrote its conclusion. ${ }^{2}$ For the first time, I used my experience in politics and policymaking as primary sources for scholarly writing. I had begun to invite readers to judge my experience as they would any other evidence.

I have used personal experience as a source, along with standard primary and secondary sources, in most subsequent articles and public talks. The Narrator and the Bureaucrat have also converged. 
This page intentionally left blank 